УДК 94 (477.74) «1905/1919»

DOI: https://doi.org/10.33782/eminak2020.3(31).438

\title{
ІЗМАЇЛЬСЬКА СТАРООБРЯДНИЦЬКА ЄПАРХІЯ: ПРОБЛЕМА ПОШУКУ ВЛАСНОГО ЄПИСКОПА (1906-1919 РР.)
}

\author{
Алла Федорова \\ Одеський національний політехнічний університет (Одеса, Україна) \\ e-mail: alla_F2006@ukr.net \\ ORCID: https://orcid.org/0000-0002-0306-7804
}

\begin{abstract}
У статті розглянута історія Ізмаїльської старообрядницької єпархії в 1906-1919 рр. В цей період вона припинила існувати як самостійна єпархія, опинилася під тимчасовим управлінням різних єпископів - спочатку Іоанна Московського, потім колишніх неокружників Петра Бессарабського та Кирила Одеського і Балтського. Це викликало занепокоєння місцевих старообрядців, які майже щорічно подавали прохання Освяченому Собору старообрядницьких єпископів поставити їм власного єпископа, навіть пропонували кандидатури - Арсенія Уральського, Інокентія Нижегородського, Олексія Богатенкова, Михайла Семенова тощо, але безрезультатно. Відродження самостійної Ізмаїльської єпархії сталося лише після переходу Бессарабії до Румунії.
\end{abstract}

Ключові слова: Ізмаїльська старообрядницька єпархія, пошуки єпископа, Освячений Собор, неокружники

Старообрядництво, як явище, з'явилося у середині XVII ст. після церковної реформи патріарха Никона. Прибічники старої віри, зазнаючи утиски як з боку офіційної православної церкви, так і з боку держави, щоб уберегти свою віру, давні звичаї та традиції, змушені були тікати на окраїни Росії і, навіть, за її межі. Так вони опинилася у Польщі, Прибалтійських країнах, Австрії, Угорщині, Пруссії, Туреччині тощо.

3 часом у старообрядницькому середовищі постає проблема з ієрархами. Якщо спочатку старообрядцям-поповцям вдавалося приєднувати до себе священиків і дияконів з новообрядницької церкви, то у 1822 р. російський імператор Олександр I наклав на це заборону. За правління Миколи I ситуація лише погіршилася, що спонукало старообрядців до заснування власної єпископської кафедри за кордоном.

У 1846 р. в Австро-Угорщині постала Білокриницька трьохчинна старообрядницька ієрархія на чолі з боснійсько-сараївським митрополитом Амвросієм‥ Наступного року за вимогами російського уряду австрійська влада змусила митрополита Амвросія покинути Білу Криницю, його заточили до фортеці Циллі. Але це не змогло перервати новоствореної ієрархії, оскільки Амвросій встиг висвятити двох єпископів - Кирила Майноського та Аркадія Славського. Місце Амвросія зайняв Кирило. Білокриницька ієрархія швидко поширювалася, засновувалися старообрядницькі єпархії, у т.ч. і в Росії, де у 1863 р. постала архієпископія Московська та всієї Русі.

У 1881 р. між Білокриницькою митрополією та Московською архієпископією підписана згода про поділ приходів та єпархій: ті, що знаходяться на території Росії, підпорядковуються московському архієпископу, а закордонні - білокриницькому митрополиту. Однак з підпорядкуванням не завжди все було гладко, часом виника-

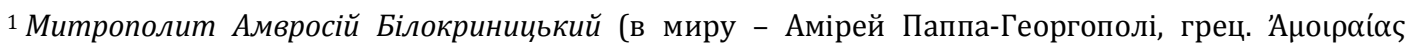

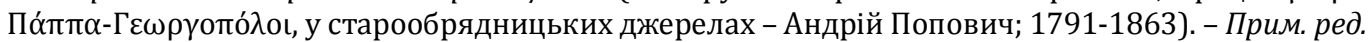


ли проблеми з приводу приналежності тієї чи іншої єпархії, що ми можемо спостерігати і сьогодні.

У цьому сенсі яскравим прикладом виступає Ізмаїльська єпархія, яка через своє геополітичне розташування неодноразово переходила до складу різних держав: то Молдавського князівства, то Румунії, то Росії тощо.

Розглянемо коротко історію створення та становлення Ізмаїльської єпархії. 22 серпня 1854 р. митрополитом Кирилом на прохання бессарабських старообрядців для них був поставлений в єпископи Аркадій Васлуйський. У 1857 р. він був переведений до Ізмаїлу, де була влаштована архієпископська кафедра. Місцем резиденції Аркадія в Ізмаїлі стала церква Святого Миколая Чудотворця. Аркадій став першим архієпископом Ізмаїльської єпархії. Служив на цій посаді до 2 листопада 1877 р. У 1861 р. був визнаний у сані архієпископа румунською владою (у підпорядкуванні якої знаходилася Бессарабія), не дивлячись на протести румунських архієреїв.

За наступного архієпископа, Віссаріона (06.12.1877 - 27.01.1881), який був переведений з Тульчинської єпархії до Ізмаїльської, територія Бессарабії за Берлінським трактатом 1878 р. відійшла до Російської імперії. I, мабуть, через геополітичні міркування, за старообрядцями були визнані права та привілеї, якими вони користувалися до об’єднання з Росією.

Третім єпископом став ігумен Петро-Павлівського монастиря (біля м. Вилкова) Анастасій (08.03.1881 - 13.02.1906). Ця авторитетна людина правила Ізмаїльською єпархією 25 років. Єпископ Анастасій активно боровся з утисками проти старообрядців єпархії, оскільки уряд намагався прирівняти їх в правах зі старообрядцями основної частини Росії. Але єпископу Анастасію здебільшого вдавалося підтверджувати колишні права та привілеї.

У представленій статті ми звернемо увагу на доволі складний період в історії Ізмаїльської єпархії, коли вона після 25-річного правління єпископа Анастасія з 1906 по 1919 р. опинилася у тимчасовому підпорядкуванні єпископів інших єпархій. Це не влаштовувало старообрядців регіону, які звикли вже до власного владики, який слідкував за становищем справ в єпархії, опікувався ними, активно відстоював їхні права. 3 ситуацією, що склалася, вони миритися не хотіли, що вилилося у чисельні прохання поставити власного єпископа та відродити самостійну єпархію. Особливо яскраво це відображено в документах, які містяться у фонді Канцелярії архієпископа Московського та всієї Русі Російського державного архіву давніх актів. Ці матеріали стали основною джерельною базою для підготовки статті.

Що стосується історіографії питання, то зазначимо, що загальну характеристику Ізмаїльської єпархії подав ще відомий апологет старообрядництва Ф. Мельников², окремі аспекти діяльності Ізмаїльської єпархії з часів її становлення розглядалися у статтях С. Таранця, дисертаційних роботах і статтях А.Федорової ${ }^{4}$ та

\footnotetext{
2 Мельников Ф.Е. Краткая история древлеправославной (старообрядческой) церкви. Барнаул, 1999. С. 322-323.

3 Таранец С.В. Состояние веры у старообрядцев Южной Бессарабии (XIX - начало XX вв.) // Старообрядчество: история, культура, современность. Материалы. Москва, 2000. С. 103-112; Таранець С.В. Старообрядці в Південній Бессарабії (від початку поселення до 1917 р.) // Наукові записки. Збірник праць молодих вчених та аспірантів Інституту української археографії та джерелознавства імені М.С. Грушевського НАН України. Київ, 2001. Т. 7. С. 61-91.

4 Федорова A.I. Старообрядницькі общини Південної Бессарабії у XIX - першій половині XX ст.: історико-конфесійний аспект: Дис... канд. іст. наук: 07.00.01 / Одеський національний політехнічний ун-т. Одеса, 2005. 238 с.; Федорова A.I. Анастасій - єпископ Ізмаїльської старообрядницької
} 
I. Кучерявенко 5 . Доволі грунтовно відображено період так званої «феогенової смути»6 в Ізмаїльській єпархії, коли також поставало питання з підпорядкуванням. Однак окреслений нами період 1906-1919 рр. не отримав належного висвітлення - дослідники тільки називали імена єпископів, до управління яких входила єпархія, а ставлення до цього місцевих старообрядців, власне, проблема вибору єпископа на Ізмаїльську кафедру не стала предметом спеціального дослідження. Виняток складає лише 1911 р.: цей період розглядався А.І. Федоровою на основі матеріалів Центрального державного історичного архіву України в м. Києві та місіонерських звітів7. Отже, у представленій роботі автор, на основі архівних документів, більшість з яких вперше вводиться до наукового обігу, спробує з'ясувати митарства старообрядців Ізмаїльської єпархії впродовж 1906-1919 рр., дізнатися причини незадоволення поставленими єпископами та виявити імена бажаних кандидатів на кафедру.

Положення старообрядництва в Росії значно поліпшилося після видання 17 квітня 1905 р. указу «Про укріплення начал віротерпимості». Це сприяло активізації діяльності старообрядців в усіх напрямках: систематично скликаються Всеросійські з'їзди старообрядців, реконструюються та споруджуються нові культові споруди, відкриваються школи, училища тощо. У 1906 р. Освячений Собор старообрядницьких єпископів (Собори почали збиратися у Москві за правління московського архієпископа Іоанна (Картушина) щорічно з 1898 р. для вирішення найбільш важливих справ) оголосив фактичну незалежність російської ієрархії від білокриницької. Влада білокриницького митрополита простягалася лише до російських кордонів.

13 лютого 1906 р. помирає ізмаїльський єпископ Анастасій. 18 лютого 1906 р. на його поховання до Ізмаїлу приїхали московський архієпископ Іоанн (Картушин), єпископ Арсеній (Швецов) та апологет старообрядництва Климент Перетрухін8. Після смерті ізмаїльського єпископа єпархію взяв під своє управління московський архієпископ.

єпархії // Інтелігенція і влада. Серія: історія. Вип. 9. Одеса, 2007. С. 243-250; Федорова А.І. Старообрядницька Ізмаїльська єпархія (50-і рр. XIX ст. - 40-і рр. XX ст.) // Науковий вісник. 2008. № 20 (76). С. 167-177 й ін.

5 Кучерявенко І.Ф. Ізмаїльсько-Бессарабська старообрядницька єпархія як історико-культурний та конфесійний феномен (1857-1946 рр.): Дис... канд. іст. наук: 07.00.01 / Ізмаїльський державний гуманітарний ун-т. Ізмаїл, 2007. 251 арк.; Кучерявенко І.Ф. Духовний центр старообрядництва на Півдні України // Проблеми історії України XIX - початку XX ст. Вип. IX. Київ, 2005. С. 239-245; Кучерявенко І.Ф. Ізмаїльсько-Бессарабська старообрядницька єпархія: основні аспекти діяльності (1857-1946) // Науковий вісник Ізмаїльського державного гуманітарного університету. 2009. Вип. 26. С. 7-11 та ін.

6 Панкратов А. Деятельность Федора Ефимовича Мельникова в старообрядческой Измаильской епархии в середине 1930-х годов // Духовные ответы. 2000. Вып. 13. С. 65-78; Панкратов А. Как мирянин не дал митрополиту сжечь «Кормчую» // Независимая газета - религии. 2000. 26 апреля. URL: https://samstar-biblio.ucoz.ru/publ/51-1-0-671; Федорова А.И. Ситуация в Измаильской епархии в 30-х гг. ХХ в. // Липоване: история и культура русских-старообрядцев. Одесса, 2005. Вып. II. C. 59-64; Федорова A.I. Початок протистояння: старообрядницькі єпископи Інокентій та Феоген (20-ті роки ХХ ст.) // Південь України: етноісторичний, мовний, культурний та релігійний виміри: зб. наук. праць II Міжнар. наук.-практ. конф, 10-11 квітня 2009 р. Одеса: ВМВ, 2009. C. 356-361.

7 Федорова А.І. Старообрядницька Ізмаїльська єпархія (50-і рр. XIX ст. - 40-і pp. XX ст.) // Науковий вісник. 2008. № 20 (76). С. 173-174.

8 Старообрядчество в Херсонской епархии // Херсонские епархиальные ведомости. 1906. № 14. отд. неоф. С. 352. 
Вже 7 березня 1906 р. благочинний Ізмаїльської єпархії Трофим Чигин, звітуючи архієпископу Іоанну про стан справ в єпархії, висловлював сподівання «что не оставите нас сирых, пошлете нам другого (єпископа. - Aвт.), который наставит нас на путь спасения, и вразумит нас»9. А «вразумляти», дійсно, було кого: в єпархії виявилося чимало проблем, зокрема, з нащадками покійного єпископа Анастасія, неулагоджені фінансові справи, негаразди у монастирях тощо. За таких обставин потрібна була досить авторитетна особа на чолі єпархії, яка б змогла навести лад.

31906 р. на розгляд Освячених соборів старообрядницьких єпископів постійно надходили прохання старообрядців поставити на Ізмаїльську кафедру власного єпископа і, власне, відродити ії як самостійну одиницю.

20 квітня 1906 р. мав відбутися черговий Освячений собор. На його розгляд старообрядці Ізмаїльської єпархії надіслали доповідь, де, зокрема, намагалися дізнатися причину ліквідації єпархії: «...наша Измаильская кафедра, бывшая архиепископия, упразднена на время. А именно по какой причине ко общему нашему прискорбию, никому ничего не известно» ${ }^{10}$. На загальних зборах прихожан Ізмаїльської старообрядницької Свято-Миколаївської кафедральної церкви 4 квітня 1906 р. було вирішено просити Освячений собор призначити на овдовілу Ізмаїльську єпископську кафедру видатного діяча старообрядництва Арсенія Швецова, єпископа Уральського. У випадку неможливості задовольнити прохання, просили зробити вибір за розсудом Собору. Цю пропозицію підтримали старообрядці Болграда, Вилкова, Кілії, Жебріян, Карячкова, Подковки, Муравльовки, Рені, Старої та Нової Некрасівок ${ }^{11}$. Одеська община також зголосилася «вместе с ними ходатайствовать пред Освященным собором о возрождении Измаильской архиепископии и о назначении на оную старейшую архиепископию преосвященнейшего Арсения епископа Уральского»12. Але ізмаїльцям не судилося мати таку освічену людину у себе єпископом. Арсеній Уральський був засновником Всеросійських з'їздів старообрядців білокриницької згоди, сприяв налагодженню зібрання Освячених соборів, намагався примирити окружників і неокружників.

Ще у 1862 р. Ксеносом (Іларіоном Кабановим) видано «Окружне послання», через яке в Білокриницькій ієрархії стався розкол: прибічників цього документа стали називати «окружниками», а противників - «неокружниками», «роздорниками», «противоокружниками». Питання об'єднання окружників і неокружників неодноразово розглядалося, і саме з 1906 р. вийшло на фінішну пряму. 4 червня 1906 p. у Москві був підписаний акт про примирення: 3 боку окружників архієпископом Московським Іоанном, єпископами Арсенієм Уральським та Інокентієм Нижегородським, а $з$ боку неокружників - єпископом Новозибківським Михайлом, одеським священиком Стефаном Кравцовим (майбутнім очільником Ізмаїльської єпархії (1935-1939) та Білокриницької єпархії (1939-1941)) й іншими священнослужителями ${ }^{13}$. Однак повного примирення не вдалося досягти. 9 квітня 1907 р. підписано Бендерський мирний акт єпископами Інокентієм Нижегородським і Костромським, Кирилом Балтським і Одеським, Петром Бессарабським, Кипріаном Тверським та іншими священно-

\footnotetext{
9 Российский государственный архив древних актов (далі - РГАДА). Ф. 1475. Оп. 1. Д. 240. Л. 7.

10 РГАДА. Ф. 1475. Оп. 1. Д. 20. Л. 65-66.

11 РГАДА. Ф. 1475. Оп. 1. Д. 20. Л. 61-66; Д. 240. Л. 90-91.

12 РГАДА. Ф. 1475.Оп. 1. Д. 19. Л. 3-За; Д. 20. Л. 39 об.

13 РГАДА. Ф. 1475. Оп. 1. Д. 402. Л. 42
} 
служителями та мирянами ${ }^{14}$. Цей акт особливе значення мав саме для Півдня, з цього часу почалося активне єднання, у чому велику роль відігравали й Освячені Собори.

Серед постанов Освяченого собору від 25 вересня 1906 р. з приводу розподілу єпархій єпископів, що примирилися, є цікава ухвала - доручити тимчасово Ізмаїльську єпархію веденню та нагляду єпископа Михайла Новозибківського (який підписав 1906 р. мирний акт між окружниками та неокружниками у Москві). Очевидно, в Ізмаїльській єпархії з цим кардинально не погодилися, оскільки не бажали мати неокружника, навіть колишнього, на чолі єпархії. Зазначимо, що покійний єпископ Анастасій був окружником.

Відомо, що після собору старообрядці Ізмаїльської єпархії запропонували поставити на кафедру Олексія Прокопійовича Богатенкова ${ }^{15}$, праву руку архієпископа Іоанна, очільника Канцелярії архієпископа московського та всієї Русі. Але знову не вийшло: у 1907 р. він був висвячений у сан єпископа Рязанського та Єгоріївського.

Через рік після смерті Анастасія прохання повторюються. 14 лютого 1907 р. Т. Чигин повідомляв архієпископа Іоанна, що по єпископу Анастасію відслужили святі та божественні літургії за участі великої кількості тих, що моляться, і після обіду народ знову підняв питання відносно власного єпископа ${ }^{16}$. Своє рішення старообрядці регіону обумовлювали тим, що єпархія знаходиться під управлінням архієпископа Іоанна, у якого своя паства дуже велика, тому сил не них бракує; скаржилися, що їм тяжко живеться без власного єпископа; також зазначали, що особливо важко усвідомлювати, що за часів Румунської держави окрема Ізмаїльська кафедра існувала, а в Росії - ні.

3 червня 1907 р. в Ізмаїлі на зборах уповноважених від старообрядницьких общин Ізмаїльської єпископії знову розглядалося питання вибору єпископа, його утримання: ухвалили асигнувати на утримання єпископа 1215 руб., просити про переведення на Ізмаїльську кафедру єпископа Інокентія Нижегородського та Костромського з возведенням його на сан архієпископа ${ }^{17}$. Таке рішення виникло не випадково. У квітні 1907 р. Інокентій (Усов) відвідав Ізмаїл, його промова про користь просвітництва в дусі старообрядництва справила велике враження на місцевих старообрядців, завдяки його підтримці та безпосередній участі в місті відкрилося училище ${ }^{18}$. Ізмаїльці зазначали: «Сей владыка принесет для нашего, беднаго просвещением края великую пользу; такую же пользу он принесет и соседней нам епархии Тульчинской, населенной беглопоповцами и штундистами» ${ }^{19}$. Тульчинська єпархія, після возведення ії̈ єпископа Макарія 10 вересня 1906 р. в сан білокриницького митрополита, також залишилася без власного єпископа. Ізмаїльці пропонували об’єднати дві єпархії під владою єпископа Інокентія (Усова), але тут зачіпалися інтереси Білокриницької митрополії, оскільки старообрядці Румунії знаходилися в ї̈ підпорядкуванні. Правда, ізмаїльці трохи запізнилися з проханням - 13 травня 1907 р. Тульчинську єпархію очолив єпископ Іосаф 20.

\footnotetext{
141907 г., июнь, Москва // Русская Православная Старообрядческая Церковь. URL: http://rpsc.ru/misc/other/1907-g-iyun-moskva/

15 РГАДА. Ф. 1475. Оп. 1. Д. 23. Л. 44; Д. 240. Л. 43об.

16 РГАДА. Ф. 1475. Оп. 1. Д. 241. Л. 40 об.

17 РГАДА. Ф. 1475. Оп. 1. Д. 23. Л. 43.

18 Г. Измаил // Церковь. 1908. № 46. С. 1402-1403.

19 РГАДА. Ф. 1475. Оп. 1. Д. 23. Л. 44об.

20 Мельников Ф. Указ. соч. С. 318.
} 
Прохання старообрядців Ізмаїльського регіону щодо єпископа Інокентія отримало відмову, що пояснювалася тим, що ввірена йому Нижегородська єпархія має важливе значення серед старообрядців, передусім, як місце проведення з'їздів старообрядців всієї Росії, тому тут потрібен такий діяльний єпископ, як Інокентій 21.

23 липня 1907 р. Освячений Собор ухвалив доручити тимчасово Ізмаїльську єпархію єпископу Петру Бессарабському, пояснюючи таке рішення справами миру та тісного єднання з нами як самого єпископа Петра (нагадаємо, Петро (Іванов) - колишній неокружник, примирився з окружниками на Бендерському соборі. - Aвт.), так і всіх християнських громад тієї місцевості, щоб згодом могла утворитися єдина Бессарабсько-Ізмаїльська єпархія під управлінням самостійного єпископа ${ }^{22}$. Собор добре розумів, що місцеві старообрядці не такого рішення чекають (рік назад вони не прийняли Михайла Новозибківського), тому поспішив зробити до ухвали приписку: «Извещая о сем просим Вас с сыновним послушанием принять это соборное постановление...»²3. Слід взяти до уваги і той факт, що після Бендерського примирення, 14 червня 1907 р. у Вилковому відбулися збори представників різних приходів Ізмаїльської єпархії. За їх результатами був написаний лист архієпископу Іоанну про незгоду з кандидатурою єпископа Петра, а також попередження єпископу Петру, щоб «не трогался со своего места, дабы вышло все благо». Просили Петра не приїздити до приходів Бессарабії, поки не увійдуть прихожани в єдину згоду щодо його кандидатури ${ }^{24}$.

Отже, єпископ Петро не задовольнив місцевих старообрядців, листи з проханням поставити власного єпископа продовжували надходити до Освяченого Собору і в 1908 р. Рішенням Собору від 27 липня 1908 р. кафедра залишалася під управлінням єпископа Петра. Ця ухвала офіційно була зачитана 6 грудня 1908 р. в Ізмаїльському єпископському домі у присутності єпископа Петра, священнослужителів і громадських депутатів. Однак зібрання знову одностайно вирішило просити єпископів Освяченого Собору обрати на Ізмаїльську кафедру місцевого єпископа 25.17 грудня було написано роз'яснення від архієпископа Іоанна: Ізмаїльська кафедра залишилася під наглядом єпископа Петра, тому що немає кандидата, шукають ${ }^{26}$. На наш погляд, такі відповіді виглядають дещо дивними, адже на інші кафедри в Росії ставилися нові єпископи, відкривалися навіть нові єпархії. Скоріш за все, прикордонне розташування Ізмаїльської єпархії зупиняло Московську архієпископію відносно рішення про ставлення власного єпископа. Мотивація підпорядкування Ізмаїльської кафедри, яка завжди була окружницькою, колишнім неокружникам, на наш погляд, ніяк не сприяло справі єднання.

Боротьба за єпископа тривала. Про нагальну необхідність обрання власного єпископа зазначалося у доповіді уповноваженого Ізмаїльської єпархії Акіндіна Сергійовича Москвічова з посада Вилково Освяченому собору, що датується 27 січня 1909 р.: «...Бессарабия после смерти епископа Анастасия лишилась истинного пастыря и вновь мрак окутал наши души... Владыка Петр не только не в состоянии руководить нами, но еще больше опутал нас, отчего и получился неблагоприятный для еписко-

\footnotetext{
21 РГАДА. Ф. 1475. ОП. 1. Д. 24. Л. 16.

22 Ibid. Л. 14, 16, 19, 47.

23 Ibid. Л. 14.

24 РГАДА. Ф. 1475. Оп. 1. Д. 403. Л. 58-58об.

25 РГАДА. Ф. 1475. Оп. 1. Д. 28. Л. 4.

26 Ibid. Л. 5.
} 
па Петра результат. Собрание всех попечителей от обществ 6-го декабря выразило волю свою не в пользу епископа Петра, ибо ему назначили половину содержания за епископство. Мы имеем выход из нашего положения, но нет вождя, могущего спасти нас. И вот решили просить Вас преосвященные владыки, дать нам новаго епископа...»27. Отже, місцеві старообрядці висловили недовіру єпископу Петру, зменшили вдвічі його жалування. Вони наполягали, що врятувати бессарабців міг «пастырь, жертвующий собой и имеющий развитие и развитие всестороннее, как например епископ Иннокентий». Але ж Освячений собор не затвердив цю кандидатуру, тому уповноважені від Ізмаїльської єпархії показували, до яких негативних наслідків це призводить: «люди наши часто смешиваются с иностранцами, смотря на них курят табак, бреют бороды, забывают посты, но что хуже всего, то это укоренение матерного слова» ${ }^{28}$. Саме тому просили призначити на кафедру такого пастиря, який зумів би «засветить светильник в душах человеческих светом благоразумия и напоить жаждущих божественной водой и сумел бы вывести нас на истинный Христов путь» ${ }^{29}$, наприклад, о. Георгія Лакомкіна або о. Ісідора Андронова. Але і ця пропозиція не отримала підтримки.

У 1910 р. єпископ Петро прийняв схиму в збудованому ним Муравльовському монастирі поблизу Ізмаїлу, єпархія тимчасово доручена єпископу Кирилу Одеському та Балтському, знову таки колишньому неокружнику, який активно сприяв справі об'єднання.

У 1911 р. у процесі підготовки до Освяченого собору, який мав відбутися 25 серпня, старообрядці Ізмаїльської єпархії постійно вагалися. 3 липня 1911 р. общини Ізмаїльської єпархії вирішили виборного представника на Собор не направляти, оскільки нема потреби: кандидатури єпископа нема, владикою Кирилом поки задоволені ${ }^{30}$. Але через місяць, 7 серпня 1911 р., вони знову збираються при Миколаївській церкві в Ізмаїлі у складі 15 представників від усіх старообрядницьких общин Ізмаїльського повіту, з'їзд очолив священик Т. Чигина. На посаду єпископа був обраний єпископ Михайло (Павло Васильович Семенов), колишній архімандрит і професор Санкт-Петербурзької духовної академії, який перейшов у старообрядництво та був посвячений у 1907 р. у сан єпископа у Нижньому Новгороді старообрядницьким єпископом Інокентієм (Усовим). Можливо, саме дружні стосунки єпископа Михайла з Інокентієм, сприяли прийняттю такого рішення. Хоча, слід наголосити, що священики та делегати похилого віку були проти призначення єпископа Михайла на Ізмаїльську єпархію, однак більшість делегатів підтримала цю кандидатуру.

Офіційною причиною вибору єпископа Михайла було «бажання старообрядців підняти своїх одновірців щодо загальної освіти, а також налагодити господарську частину при церковних общинах, що прийшли у занепад після смерті останнього єпископа»31. Місіонери вказували, що вакантну Ізмаїльську єпископську кафедру в 1911 р. мав очолити єпископ Уральський Мефодій ${ }^{32}$. Делегати, які клопотали у Москві про призначення нового єпископа на Ізмаїльську єпархію, священик Кілії Іоанн

\footnotetext{
27 РГАДА. Ф. 1475. Оп. 1. Д. 28. Л. 41.

28 Ibid. Л. 41 об.

${ }^{29}$ Ibid. Л. 42.

30 РГАДА. Ф. 1475. Оп. 1. Д. 43. Л. 6.

31 Федорова А.І. Старообрядницька Ізмаїльська єпархія (50-і pp. ХІХ ст. - 40-і pp. XX ст.) // Науковий вісник. 2008. № 20 (76). С. 174.

32 Воловей Ф. Раскол и противораскольническая миссионерская деятельность в Кишиневской епархии в 1912 г. // Кишиневские епархиальные ведомости. 1913. № 22-23. Приложение. С. 6.
} 
Чернов і мешканець Ізмаїлу Сава Гусляков, повернулися ні з чим, відповідь вже традиційна - кандидатуру шукають 33 .

У 1912 р. Освячений собор трохи змінює тактику: доручає архієпископу Іоанну увійти в зносини з білокриницьким митрополитом Макарієм відносно переводу на Ізмаїльську кафедру єпископа Славського Леонтія разом з приходами цієї єпархії, якщо дозволить митрополит Макарій і Славська єпархія не буде проти ${ }^{34}$. Звісно, білокриницький митрополит Макарій не погодився добровільно віддати свій приход на користь Росії.

20 липня 1913 р. знову збирається з'їзд Ізмаїльської овдовілої єпархії, де обирається комісія щодо пошуку кандидата на єпископи, при чому приймається рішення: якщо кандидата на соборі не знайдуть, то залишити єпархію під тимчасовим наглядом владики Кирила 35 . Освячений собор 25 серпня 1913 р. вирішив реалізувати ухвалу 1907 р. - об'єднати Бессарабську й Ізмаїльську єпархії та підпорядкувати її веденню єпископа Одеського Кирила 36.

6 липня 1914 р. представники старообрядницьких общин Ізмаїльського повіту вирішили не посилати в Москву на Освячений собор депутатів, оскільки, по-перше, кінець серпня $є$ найбільш гарячою порою року, нема часу на поїздку, а по-друге, у старообрядців єпархії не має невідкладних питань для вирішення Собору37. 3 цього можемо зробити висновок, що старообрядці Ізмаїльської єпархії поступово змирилися з ситуацією, що склалася.

У 1914 р. архієпископ московський Іоанн помер. Очолити єпархію пропонували білокриницькому митрополиту Макарію, який в цей час перебував у Росії і через війну не міг потрапити до Білої Криниці, але він відмовився. Новим архієпископом був обраний Мелетій. Архівні документи 1915-1916 рр. не містять вже прохань ізмаїльців щодо вибору єпископа, і взагалі у період війни старообрядницькі зібрання стали малочисельними; 1917-1918 рр. взагалі не представлені в архіві, що можна пояснити революційними подіями.

Отже, питання власного єпископа на Ізмаїльській кафедрі вирішилося лише з переходом території Бессарабії до Румунії. 27 жовтня 1919 р. на Ізмаїльську кафедру був поставлений білокриницьким митрополитом Макарієм єпископ Феоген, з чиїм ім'ям пов'язана так звана смута, яка, на наш погляд, також обумовлена розподілом єпархій між Москвою та Білою Криницею, як, певним чином, і в період, що розглядається нами.

З 1906 по 1919 рр. старообрядці овдовілої Ізмаїльської єпархії активно виборювали право на існування окремої кафедри з власним єпископом на чолі. Запропоновані ними авторитетні особи - Арсеній Швецов, Олександр Богатенков, Інокентій Усов, Михайло Семенов та інші, які могли підняти рівень просвіти у регіоні, владнати внутрішні негаразди, так і не стали на чолі єпархії. Ізмаїльська єпархія передавалася в управління винятково колишнім неокружникам, що викликало незадоволення. Московська архієпископія побоювалась втратити цю єпархію, саме цим, на наш погляд, можна пояснити пропозиції об’єднати якусь закордонну єпархію - Тульчин-

33 РГАДА. Ф. 1475. Оп. 1. Д. 41. Л. 16; Д.44. Л. 28; Центральний державний історичний архів у м. Києві. Ф. 1152. Оп. 1. Спр. 224. Арк. 56-56зв.; Воловей Ф. Указ. соч. С. 6.

34 РГАДА. Ф. 1475. Оп. 1. Д. 45. Л. 2а.

35 РГАДА. Ф. 1475. Оп. 1. Д. 248. Л. 2.

36 РГАДА. Ф. 1475. Оп. 1. Д. 46. Л. 11.

37 РГАДА. Ф. 1417. Оп. 1. Д. 47. Л. 24. 
ську чи Славську з Ізмаїльською, щоб таким чином Російська імперія отримала додаткові єпархії у підпорядкування.

\section{REFERENCES}

Fedorova, A.I. (2005). Situatsiia v Izmailskoi eparkhii v 30-kh gg XIX v. [The situation in the Izmail diocese in the 30s of XX century]. Lipovane: istoriia i kultura russkikh-staroobriadtsev (Vol. II, pp. 5964). Odessa [in Russian].

Fedorova, A.I. (2005). Staroobriadnytski obshchyny Pivdennoi Bessarabii u XIX - pershii polovyni XX st.: istoryko-konfesiinyi aspect [Old-believers communities of Southern Bessarabia in the XIX - the $\mathrm{l}^{\text {st }}$ half of XX centuries: historical and confessional aspect]. (Candidate's thesis). Odesa [in Ukrainian].

Fedorova, A.I. (2007). Anastasii - yepyskop Izmailskoi staroobriadnytskoi yeparkhii [Anastasiy, the the bishop of Izmail old-believers diocese]. Intelihentsiia i vlada. Seriia: istoriia, 9, 243-250 [in Ukrainian].

Fedorova, A.I. (2009). Pochatok protystoiannia: staroobriadnytski yepyskopy Inokentii ta Feohen (20-ti roky XX st.) [The beginning of the confrontation: Old Believer bishops Innocent and Theogen (1920s)]. Abstracts of Papers - 2009: Pivden Ukrainy: etnoistorychnyi, movnyi, kulturnyi ta relihiinyi vymiry, (pp. 356-361). Odesa [in Ukrainian].

Fedorova, A.I. (2008). Staroobriadnytska Izmailska yeparkhiia (50-i rr. XIX st. - 40-i rr. XX st.) [Old Believer Izmail Diocese (50s of the XIX century - 40s of the XX century)]. Naukovyi visnyk, 20 (76), 167-177 [in Ukrainian].

Kucheriavenko, I.F. (2005). Dukhovnyi tsentr staroobriadnytstva na Pivdni Ukrainy [Spiritual center of Old Believers in the South of Ukraine]. Problemy istorii Ukrainy XIX - pochatku XX st., (IX), 239-245 [in Ukrainian].

Kucheriavenko, I.F (2007). Izmailsko-Bessarabska staroobriadnytska yeparkhiia yak istoryko-kulturnyi ta konfesiinyi fenomen (1857-1946 rr.) [Diocese of Izmail staroobryadchestvo as an historic-cultural and confession phenomenon (1857-1946 )]. (Candidate's thesis). Izmail [in Ukrainian].

Kucheriavenko, I.F. (2009). Izmailsko-Bessarabska staroobriadnytska yeparkhiia: osnovni aspekty diialnosti (1857-1946) [Izmail-Bessarabian Old Believer Diocese: main aspects of activity (18571946)]. Naukovyi visnyk Izmailskoho derzhavnoho humanitarnoho universytetu, 26, 7-11 [in Ukrainian].

Melnikov, F.E. (1999). Kratkaia istoriia drevlepravoslavnoi staroobriadcheskoi tserkvi [A Brief History of the Old Orthodox (Old Believer) Church]. Barnaul [in Russian].

Pankratov, A. (2000). Deiatelnost Fedora Efimovicha Melnikova v staroobriadcheskoi Izmailskoi eparkhii v seredine 1930-kh godov [The activities of Fedor Efimovich Melnikov in the Old Believer Izmail diocese in the mid-1930s]. Dukhovnye otvety, 13, 65-78 [in Russian].

Pankratov, A. (2000). Kak mirianin ne dal mitropolitu szhech «Kormchuiu» [How layman did not allow the Metropolitan to burn «Helmsman»]. Nezavisimaia gazeta - religii. April 26. Retrieved from: https://samstar-biblio.ucoz.ru/publ/51-1-0-671 [in Russian].

Taranets, S.V. (2000). Sostoianie very u staroobriadtsev Yuzhnoi Bessarabii XIX - nachalo XX vv. [The state of faith among the Old Believers of Southern Bessarabia (XIX - early of XX centuries)]. Staroobriadchestvo: istoriia, kultura, sovremennost Materialy, (pp. 103-112). Moskva [in Russian].

Taranets, S.V. (2001). Staroobriadtsi v Pivdennii Bessarabii (vid pochatku poselennia do 1917 r.) [Old Believers in Southern Bessarabia (from the beginning of the settlement to 1917)]. Naukovi zapysky. Zbirnyk prats molodykh vchenykh ta aspirantiv Instytutu ukrainskoi arkheohrafii ta dzhereloznavstva imeni M.S. Hrushevskoho NAN Ukrainy, (7), 61-91 [in Ukrainian].

\section{Alla Fedorova}

(Odesa National Polytechnic University, Odesa, Ukraine)

e-mail: alla_F2006@ukr.net

ORCID: https://orcid.org/0000-0002-0306-7804

\section{Izmail Old Believers Diocese: Problem of Seek for Own Bishop (1906-1919)}

Izmail Old Believers Diocese is one of the oldest Old Believers dioceses. Its foundation dates back to 1857 when the territory of Bessarabia was a part of Principality of Moldavia. The diocese was quite unusual because due to its geopolitical position it was a part of different states. Because of that fact, there were problems with its subordination, since in 
1881 Bila Tserkva Metropolitanate and Moscow Archdiocese signed an agreement on the division of parishes and dioceses according to which those located in Russia were subordinated to the Moscow Archbishop, and foreign - to the Metropolitan of Bila Tserkva. Of course, no one wanted to let someone else have their dioceses and parishes.

The first two bishops of Izmail were called archbishops, the third - Anastasii was a bishop. In 1906, after the death of bishop Anastasii, the diocese was taken over by Archbishop John of Moscow.

The attempts of Old Believers of the widowed Izmail Diocese to restore the functioning of an independent cathedra headed by its own bishop during 1906-1919 are analyzed in the paper on the basis of documents collected in the Russian State Archives of Ancient Acts, most of which are being put into scientific circulation for the first time. Almost every year they sent a request to the Local Council of Old Believers Bishops to appoint their own bishop, even offered candidacies of well-known Old Believers figures Arsenii Uralskyi, Inokentii Nyzhegorodskyi, Oleksii Bohatenkov, Mykhailo Semenov, etc. In their opinion, those authoritative persons could enlighten the region, establish an economic part in abandoned communities, but all attempts were in vain. Usually, they received the answer that the Council was looking for a candidate.

In 1907, Izmail cathedra was given for the temporary governing of the former nonEncyclical Petro Bessarabskyi. They tried to explain such a decision by the affairs of peace and close unity of the former non-Encyclicals with Encyclicals. However, the diocese could not accept Petro's governing. When he took the vows of scheme in 1910, Izmail Diocese was again given to the former non-Encyclical Bishop Kyrylo of Odesa and Balta. If from the beginning of his governing the representatives of Izmail Diocese still asked the Local Council to appoint their own bishop, then from 1914 they had already reconciled with Bishop Kyrylo, besides the political situation (World War I, the Revolution) did not help to resolve the issue.

The revival of the independent Izmail Diocese took place only after the transition of Bessarabia to Romania in 1918. On October 27, 1919, Bishop Feohen was appointed to Izmail Old Believers cathedra by Metropolitan Macarii of Bila Tserkva.

Keywords: Izmail Old Believers Diocese, seek for a bishop, Local Council, nonEncyclicals 